
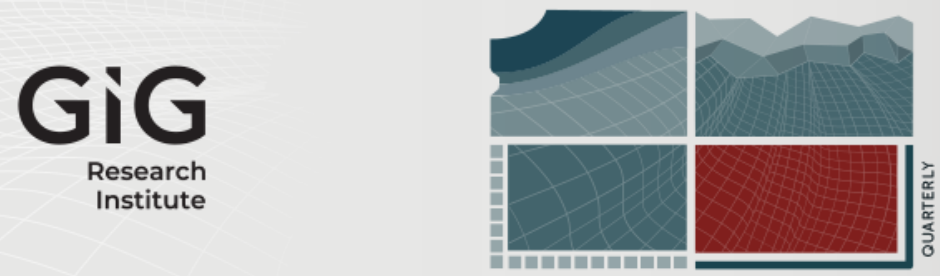

JOURNAL

OF

SUSTAINABLE

MINING

\title{
Life cycle assessment to demonstrate how automation improves the sustainability performance of an underground mining operation
}

Author(s) ORCID Identifier:

Corey Laamanen (iD) 0000-0002-1321-0491

Helen Shang (iD) 0000-0002-7647-2165

John A. Scott (iD) 0000-0002-2559-0188

Follow this and additional works at: https://jsm.gig.eu/journal-of-sustainable-mining

Part of the Environmental Studies Commons, and the Mining Engineering Commons

\section{Recommended Citation}

Moreau, Kyle; Laamanen, Corey; Bose, Ron; Shang, Helen; and Scott, John A. (2020) "Life cycle assessment to demonstrate how automation improves the sustainability performance of an underground mining operation," Journal of Sustainable Mining: Vol. 19 : Iss. 3 , Article 4.

Available at: https://doi.org/10.46873/2300-3960.1016

This Research Article is brought to you for free and open access by Journal of Sustainable Mining. It has been accepted for inclusion in Journal of Sustainable Mining by an authorized editor of Journal of Sustainable Mining. 


\title{
Life cycle assessment to demonstrate how automation improves the sustainability performance of an underground mining operation
}

\begin{abstract}
The worldwide move to introduce more automation into underground metal ore mining is currently aimed at improving both operational productivity and safety. We have used a comparative life cycle assessment (LCA) as a novel approach for the industry to determine the beneficial impacts automation can also have on environmental performance using data collected on mine site productivity and energy consumption. The LCA looked at four impact categories: global warming potential, acidification, eutrophication, and human toxicity. When comparing key automated equipment to their traditional manual counterpart, all four impact categories experienced a reduction with automation and a subsequent improvement in sustainability performance. Global warming potential, for example, decreased by $18.3 \%$ over the mine life period, or $3.7 \mathrm{~kg}$ of carbon dioxide equivalent ( $\mathrm{CO}_{2}$ eq.) per tonne of ore extracted. Environmental impact reductions were due primarily to lower diesel fuel consumption in the loading and haulage processes as well as a $27 \%$ shorter operational mine life leading to less years of mine and mine camp maintenance.
\end{abstract}

\section{Keywords}

Automation, Energy Reduction, Environmental Benefits, Life Cycle Assessment, Metals, Underground Mining

\section{Creative Commons License}

\section{(c) (7)}

This work is licensed under a Creative Commons Attribution 4.0 License.

\section{Cover Page Footnote}

The authors thank Sudbury Integrated Nickel Operations, Mitacs, Laurentian University, and the Goodman School of Mines for their continued support of our research. The authors also thank the Journal of Sustainable Mining and their reviewers for their time and contributions to this paper.

Authors

Kyle Moreau, Corey Laamanen, Ron Bose, Helen Shang, and John A. Scott 


\title{
Life cycle assessment to demonstrate how automation improves the environmental performance of an underground mining operation
}

\author{
Kyle Moreau ${ }^{a}$, Corey A. Laamanen ${ }^{a}$, Ron Bose ${ }^{b}$, Helen Shang ${ }^{a}$, John A. Scott ${ }^{a, *}$ \\ a Laurentian University, Bharti School of Engineering, Canada \\ ${ }^{\mathrm{b}}$ Glencore, XPS, Canada
}

\begin{abstract}
The worldwide move to introduce more automation into underground metal ore mining is currently aimed at improving both operational productivity and safety. A comparative life cycle assessment (LCA) was used as a novel approach to determine the beneficial impacts automation can also have on environmental performance, using data collected on mine site productivity and energy consumption. The LCA looked at four impact categories: global warming potential, acidification, eutrophication, and human toxicity. When comparing automated equipment to their traditional manual counterpart, all four impact categories experienced a reduction with automation and a subsequent improvement in sustainability performance. Global warming potential, for example, decreased by $18.3 \%$ over the mine life period, or $3.7 \mathrm{~kg}$ of carbon dioxide equivalent $\left(\mathrm{CO}_{2}\right.$ eq.) per tonne of ore extracted. Environmental impact reductions were due primarily to lower diesel fuel consumption in the loading and haulage processes as well as a $27 \%$ shorter operational mine life leading to less years of mine and mine camp maintenance.
\end{abstract}

Keywords: automation, energy reduction, environmental benefits, life cycle assessment, metals, underground mining

\section{Introduction}

$\mathrm{M}$ ining companies around the world continue to explore and assess new methods of extracting ore to improve safety and economic sustainability. Global concern of climate change and increasing restrictions on industrial emissions also obligates the mining and metallurgy industry to reduce their impacts on the environment. A life cycle assessment (LCA) technique can be used to gauge the environmental impacts of new extraction methods by quantifying the impacts of each process from raw material extraction through final use and ultimately disposal or recycling. However, while an LCA is one of the most popular methods used to quantify environmental performance, studies specifically involving mining operations have increased but are still very limited [1].

Automation has become increasingly more popular in the mining industry as companies continue to experiment with automated equipment as a method of extracting ore more efficiently, in particular as they continue to develop deeper underground [2,3]. Automated technology has become a focus for three main reasons:

(1) Safety - Automated equipment can be operated safely from the surface via remote control, removing personnel from hazards associated with the underground environment and areas with poor air quality and operating conditions such as high temperatures in deep mines $[4,5]$.

(2) Productivity - Productivity is increased through improved cycle times and operation of equipment from the surface during the blast window.

Received 12 August 2020; revised 5 October 2020; accepted 6 October 2020.

Available online 23 October 2020

* Corresponding author.

E-mail address: jascott@laurentian.ca (J.A. Scott). 
Personnel are not permitted underground during large production blasts. On average, $4-5 \mathrm{~h}$ of production is lost during the blast window per day using current manual operated equipment [3], however, automated equipment can be operated from the surface during this time to boost productivity.

(3) Maintenance - Manually operated equipment is subject to operator error, poor visibility and blind spots, leading to collisions with drift walls, excess tire wear and overwork engines [6,7]. Whereas, automated equipment is associated with fewer collisions, increased tire life, optimized driving and reduced consumption of spare parts [8].

Various LCA studies have previously been carried out to assess the environmental impacts from mining and mineral processing. A comparative LCA study was performed for three methods of tailings management for a copper zinc underground mine located in Canada. The authors reported that results from a specific site could be applied to other sites, but with caution due to differences in parameters such as ore grade, topography and other sitespecific characteristics [9]. An LCA study of iron ore and bauxite mine sites concluded that loading and haulage operations were responsible for the highest greenhouse gas (GHG) emissions, while crushing and grinding operations were the largest contributors for copper production [10]. Another study reported that copper producing mines had a wide range of total GHG emissions ( $1-9 \mathrm{t} \mathrm{CO}_{2}$ eq./t Cu.) due to differences in factors such as fuel sources, electrical energy sources and ore grade [11]. This supports the observation of Reid et al. [9], that varying mine site characteristics will have a significant impact on the total emissions produced on site.

There is, however, very limited available research on the environmental impact of autonomous equipment in the underground mining industry. This paper will focus, therefore, on comparing machine fuel efficiency, mine site energy consumption and length of mine-life for an underground metal mine operating with either manual or automated equipment to investigate their effects on the environment. This was done by using data collected from automation trials within a Canadian underground mine. The mine's use of automated LoadHaul-Dump (LHD) yielded positive results relating to increased productivity $(35 \%)$ in removing ore from the stope, as well as improved fuel efficiency which led to lower overall $\mathrm{CO}_{2}$ emissions from burning diesel fuel [12]. The environmental impacts of these trials have been analyzed here using an LCA approach.

An LCA is a technique used to assess the environmental impacts of a product's processes from raw material extraction through final use and disposal or recycling. LCAs are used to analyze the environmental contribution of each life cycle stage with the goal of identifying areas for improvement and/or to compare different products/processes [13]. An LCA is carried out by defining the goal of scope, inventory analysis, impact assessments and interpretation as shown in Fig. 1. The ISO 14040:14,043 standards were created to for the evaluation of environmental performance of a product or service throughout its operational life cycle. The standards are listed below [13]:

- ISO 14040: Overall standard which includes all four phases of the LCA study.

- ISO 14041: Standards for goal and scope definition/inventory assessment.

- ISO 14042: Standards for life cycle impact assessment methods.

- ISO 14043: Standards for life cycle interpretation methods.

\subsection{Goal and scope}

This study analyzes an underground metal mine (zinc-copper-silver-gold) whose products from the extracted ore are a zinc concentrate $(51 \% \mathrm{Zn}$.) and a copper concentrate $(21 \% \mathrm{Cu}$.), with trace metals gold and silver found within the copper concentrate. Analyses of the ore and concentrate products are provided in Table 1 in terms of the defined functional unit for this LCA study (one tonne $(t)$ of ore mined and processed).

The LCA study performed incorporates drilling, blasting, hauling, hoisting, crushing, grinding,

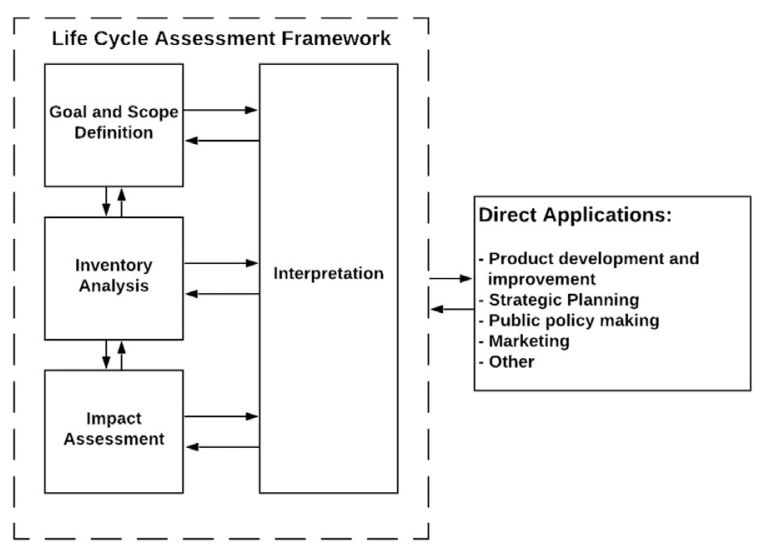

Fig. 1. Stages of an LCA study [13]. 
Table 1. Material analysis for the mined ore, zinc concentrate, and copper concentrate.

\begin{tabular}{|c|c|c|c|c|}
\hline Material & Zinc & Copper & Silver & Gold \\
\hline \multicolumn{5}{|l|}{ Ore } \\
\hline Quantity & $51.2 \mathrm{~kg} / \mathrm{t}$ & $6.9 \mathrm{~kg} / \mathrm{t}$ & $26.5 \mathrm{~g} / \mathrm{t}$ & $2.61 \mathrm{~g} / \mathrm{t}$ \\
\hline Recovery & $92.5 \%$ & $85 \%$ & $50.9 \%$ & $57.7 \%$ \\
\hline \multicolumn{5}{|l|}{ Zinc Concentrate } \\
\hline Quantity & $51 \%$ & - & - & - \\
\hline Contained Metal & $47.3 \mathrm{~kg}$ & - & - & - \\
\hline \multicolumn{5}{|l|}{ Copper Concentrate } \\
\hline Quantity & - & $21 \%$ & $\sim 0.05 \%$ & $\sim 0.005 \%$ \\
\hline Contained Metal & - & $5.87 \mathrm{~kg}$ & $13.5 \mathrm{~g}$ & $1.5 \mathrm{~g}$ \\
\hline
\end{tabular}

flotation, dewatering, and subsequent transportation of concentrated products to external refinery sites and disposal of waste tailings. Fig. 2 is a simplified process diagram showing the LCA boundaries.

The processes seen in the mining and milling sections of Fig. 1 are dependent on ore productivity, meaning as the productivity is increased from the use of automated equipment, the resources required for those processes (fuel, electricity, process water, compressed air, etc.) are also increased. However, improvements may still occur from efficiency gains of automated operations (e.g. fuel efficiency). Other processes, such as ventilation and the mine camp, remain constant when the productivity is increased, but these processes will experience significant overall reductions by eliminating approximately five years $(27 \%)$ of total operation time (Table 2).

The data obtained was extrapolated over the mine's projected life based on fixed ore reserves of 20 million tonnes. The productivity measured at the mine site for both manual and automated LHD machines is listed in Table 2 along with calculated life-of-mine. The ability to extract ore at higher daily rate was estimated to decrease the mine life by $27 \%$. It is generally expected that environmental benefits from automating underground equipment will be seen through improved fuel efficiency and energy consumption. Whereas, the effect of a reduced mine life is unknown, but may also prove to be significant in reducing overall environmental impacts. The outcomes arising from eliminating five years of mine and mill operations, mine camp related activities (water processing, landfill disposal, and energy consumption), and daily travel to and from the work site were, therefore, assessed within the LCA study.

The mine camp process considers the electricity, water and food requirement for the housing of work personnel and subsequently the wastes generated from daily living (garbage and wastewater). The mine camp process also includes emissions produced from burning gasoline for personal travel on and off site by all workers required for mine and mill operation. The existing mine workforce is comprised of 340 employees with a mine camp capacity of 198 persons. The nearest town, along with mine camp, is located $16 \mathrm{~km}$ away from the mine site. The breakdown for workers' travel is shown in Table 3 and was used to calculate emissions from daily travel to and from the worksite.

The calculation for yearly distance from the various methods of travelling to and from the mine site takes into consideration the following:

(1) As carpooling is a common method of travelling by work personnel, usually comprising of $2-4$ people per car, an average of 3 was used for this study.

(2) Personnel travelling from surrounding communities and long distances travel both ways once per week, as well as require travel from the mine camp daily.

(3) The airport is located $208 \mathrm{~km}$ from the mine site, therefore personnel who require flights also include road transportation both ways, followed by travel from the mine camp each day. Personnel travelling by air are typically members of senior management and therefore are expected to travel sporadically.

Items included within the mine and mill miscellaneous processes shown in Fig. 2 are also not affected by an increase in ore production. Operating equipment such as boom-trucks, minecats, forklifts, personnel carriers are all included within this process as well as electric energy consumption for operations unrelated to the movement of ore, which will experience a decrease of five years due to the reduction of mine life. A list of the electric utilities included within the mine and mill miscellaneous sections is provided in Table 4.

\section{Materials and methods}

The LCA study is an analysis of inputs and outputs for all the processes within the defined boundaries, 


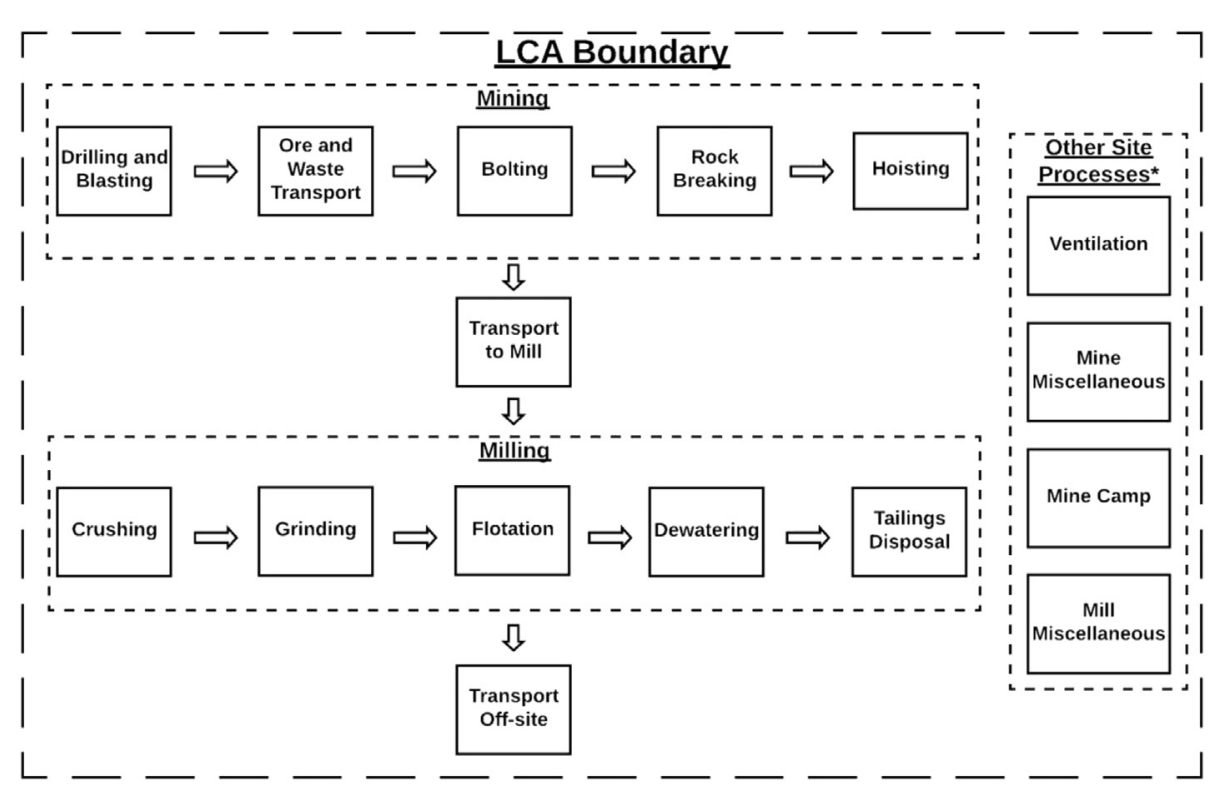

Fig. 2. Boundary for the LCA study of the investigated mine site. *Not included within the flow of ore (time-dependent).

Table 2. Operational data for manual and automated LHD operation at studied mine site.

\begin{tabular}{llll}
\hline LHD operations & Ore reserves & Production rate & Life of mine \\
\hline Manual & $20,000,000 \mathrm{t}$ & $3000 \mathrm{t} /$ day & 18.3 years \\
Automated & $20,000,000 \mathrm{t}$ & $4050 \mathrm{t} /$ day & 13.5 years \\
\hline
\end{tabular}

which include environmental inputs/outputs and those related to the Technosphere (the environment that is made or modified by humans). Table 5 provides the list of inputs/outputs for both the manual and automated operations that were examined in this LCA study with respect to the defined functional unit of mining and processing one tonne of ore. Scenario 1 contains the data obtained for entirely manual operations at the mine site. Scenario 2 analyzes the process using automated LHDs, with productivity and fuel consumption statistics taken from the trial results. Scenario 3 includes projections for additionally including automated haulage trucks and drill rigs.

\subsection{Productivity analysis}

Productivity fluctuation can be expected, especially during mine start-up and closure. Metal prices will also have an impact on the rate of mining but projecting metal prices into the future is a difficult
Table 4. Electricity requirements for operations included in the miscellaneous sections of the LCA.

\begin{tabular}{ll}
\hline Description & Electricity $(\mathrm{kWh} / \mathrm{t})$ \\
\hline Mine & \\
Underground lighting & 0.38 \\
Underground maintenance shop & 0.08 \\
Refuge stations & 0.02 \\
Welder & 0.02 \\
Exploration & 0.67 \\
Surface lighting & 0.15 \\
Surface maintenance shop & 0.06 \\
Hot water heaters & 1.38 \\
Parking lot (plug ins) & 0.27 \\
Offices & 0.03 \\
Heating & 0.28 \\
Mill & \\
Lighting & 0.22 \\
Hot water heaters & 0.55 \\
Parking lot (plug ins) & 0.11 \\
Offices & 0.01 \\
Heating & 0.28 \\
\hline
\end{tabular}

task. External demand leading to fluctuations in a mine's required production levels will be the same irrespective of the level of automation and so the average production rates were used to compare the various scenarios. In 2017, the mine reported non-

Table 3. Breakdown of travel distances for worksite personnel.

\begin{tabular}{llll}
\hline Travel type & Distance (one-way) & Personnel (\%) & Yearly travel \\
\hline Surrounding Communities & $230 \mathrm{~km}$ & $163(48 \%)$ & $1.29 \times 10^{6} \mathrm{~km}$ \\
Town & $16 \mathrm{~km}$ & $136(40 \%)$ & $2.65 \times 10^{5} \mathrm{~km}$ \\
Long distance & $700 \mathrm{~km}$ & $34(10 \%)$ & $6.87 \times 10^{5} \mathrm{~km}$ \\
Flights & $908 \mathrm{~km}$ & $7(2 \%)$ & $1.60 \times 10^{5} \mathrm{~km}$ \\
\hline
\end{tabular}


Table 5. Inventory analysis for one tonne of ore mined and processed at investigated mine site.

\begin{tabular}{|c|c|c|c|c|c|}
\hline Category & Object & $\begin{array}{l}\text { Scenario } 1 \\
\text { Manual operations }\end{array}$ & $\begin{array}{l}\text { Scenario } 2 \\
\text { Automated LHDs }\end{array}$ & $\begin{array}{l}\text { Scenario } 3 \\
\text { Automated operations }\end{array}$ & Units \\
\hline \multicolumn{6}{|c|}{ Underground operations } \\
\hline \multirow[t]{7}{*}{ Inputs from nature } & Zinc & 51.2 & 51.2 & 51.2 & $\mathrm{~kg}$ \\
\hline & Copper & 6.9 & 6.9 & 6.9 & $\mathrm{~kg}$ \\
\hline & Gold & 26.5 & 26.5 & 26.5 & $\mathrm{~g}$ \\
\hline & Silver & 2.61 & 2.61 & 2.61 & $\mathrm{~g}$ \\
\hline & Fresh water & 0.2 & 0.2 & 0.2 & $\mathrm{~m}^{3}$ \\
\hline & Fresh air (ventilation) & $4.58 \times 10^{5}$ & $4.58 \times 10^{5}$ & $4.32 \times 10^{5}$ & $\mathrm{~m}^{3}$ \\
\hline & Compressed air & 31.2 & 31.2 & 31.2 & $\mathrm{~m}^{3}$ \\
\hline \multirow[t]{5}{*}{ Materials and fuel } & Diesel fuel & 4.71 & 4.07 & 3.53 & $\mathrm{~L}$ \\
\hline & Electricity (Grid) & 85.3 & 85.3 & 82.0 & $\mathrm{kWh}$ \\
\hline & Explosives & 1.15 & 1.15 & 1.15 & $\mathrm{~kg}$ \\
\hline & Steel & 0.44 & 0.44 & 0.41 & $\mathrm{~kg}$ \\
\hline & Tires & 0.05 & 0.05 & 0.047 & $\mathrm{~kg}$ \\
\hline \multicolumn{6}{|l|}{ Mill operations } \\
\hline Inputs from nature & Fresh water & 0.86 & 0.86 & 0.86 & $\mathrm{~m}^{3}$ \\
\hline \multirow[t]{6}{*}{ Materials and fuel } & Diesel fuel & 2.09 & 2.09 & 2.09 & $\mathrm{~L}$ \\
\hline & Electricity (Grid) & 39.3 & 39.3 & 38.2 & $\mathrm{kWh}$ \\
\hline & Lime & 2.5 & 2.5 & 2.5 & $\mathrm{~kg}$ \\
\hline & Methyl Isobutyl Carbinol & 0.06 & 0.06 & 0.06 & $\mathrm{~kg}$ \\
\hline & Copper sulfate & 0.25 & 0.25 & 0.25 & $\mathrm{~kg}$ \\
\hline & Flotation chemical 3418A & 0.285 & 0.285 & 0.285 & $\mathrm{~kg}$ \\
\hline \multicolumn{6}{|l|}{ Mine camp } \\
\hline Inputs from nature & Fresh water & $9.33 \times 10^{-3}$ & $9.17 \times 10^{-3}$ & $8.76 \times 10^{-3}$ & $\mathrm{~m}^{3}$ \\
\hline \multirow[t]{3}{*}{ Materials and fuel } & Gasoline & 0.243 & 0.239 & 0.225 & $\mathrm{~L}$ \\
\hline & Electricity & 1.21 & 1.19 & 1.14 & $\mathrm{kWh}$ \\
\hline & Food and grocery & 0.042 & 0.041 & 0.039 & $\mathrm{~kg}$ \\
\hline \multicolumn{6}{|l|}{ Air emissions } \\
\hline & Carbon dioxide & 19.7 & 17.6 & 16.2 & $\mathrm{~kg}$ \\
\hline & Sulphur dioxide & 30.1 & 26.7 & 24.3 & $\mathrm{~g}$ \\
\hline & Nitrogen oxides & 354 & 316 & 287 & $\mathrm{~g}$ \\
\hline \multicolumn{6}{|l|}{ Water emissions } \\
\hline & Zinc & 3.09 & 3.09 & 3.09 & $\mathrm{~kg}$ \\
\hline & Copper & 0.68 & 0.68 & 0.68 & $\mathrm{~kg}$ \\
\hline & Gold & 0.77 & 0.77 & 0.77 & $\mathrm{~g}$ \\
\hline & Silver & 150 & 150 & 150 & $\mathrm{~g}$ \\
\hline \multicolumn{6}{|l|}{ Waste } \\
\hline & Tailings & 1.66 & 1.66 & 1.66 & $t$ \\
\hline & Scrap steel & 0.045 & 0.045 & 0.042 & $\mathrm{~kg}$ \\
\hline & Scrap tires & 0.033 & 0.033 & 0.032 & $\mathrm{~kg}$ \\
\hline & Landfill (Mine camp) & 0.02 & 0.019 & 0.018 & $\mathrm{~kg}$ \\
\hline & Sewage (Mine camp) & 0.059 & 0.058 & 0.055 & $\mathrm{~kg}$ \\
\hline \multicolumn{6}{|l|}{ Final product } \\
\hline & Zinc concentrate & 92.8 & 92.8 & 92.8 & $\mathrm{~kg}$ \\
\hline & Copper concentrate & 27.9 & 27.9 & 27.9 & $\mathrm{~kg}$ \\
\hline
\end{tabular}

automated productivity rates of $3000 \mathrm{t} /$ day and this was been used as the base productivity rate for the manual operations (scenario 1). The data gathered from the trials conducted at the mine site showed a $35 \%$ increase in productivity ( $4050 \mathrm{t} /$ day) from LHD automation, which was consistent with other reports [12] and was used for the productivity rate of automated equipment in this study.

The 35\% increase in productivity was also applied to haulage trucks and drill rigs, which are the next steps to be automated at this mine site. As ore handling from the stope using LHDs is the bottleneck within this mine's production process, daily ore tonnage would be dependent on LHD productivity and not haulage trucks or drill rigs [12]. However, productivity increases from improved cycle times and operation during the blast window would allow the mine to operate with less equipment while maintaining the $4050 \mathrm{t} /$ day production rate. With less equipment and a projected improvement in required maintenance of $15-30 \%$ (from less accident related damage) for automated equipment [14,15], it is also expected that there will be a reduction in replacement parts and scrap tire disposal throughout mine-life operations. 
Table 6. List of equipment used at investigate mine site.

\begin{tabular}{ll}
\hline Description & Fleet \\
\hline Underground trucks & 8 \\
LHD & 10 \\
Jumbo drill & 4 \\
Longhole drill & 3 \\
Bolter & 8 \\
Scissor lift trucks & 8 \\
Powder trucks & 3 \\
Boom trucks & 2 \\
Grader & 1 \\
Shotcrete sprayer & 1 \\
Trans-mixers & 2 \\
Personnel carriers & 26 \\
Miscellaneous underground (minecats, forklifts, etc.) & 19 \\
Miscellaneous surface (trucks, loader, pickups, etc.) & 22 \\
\hline
\end{tabular}

\subsection{Fuel consumption analysis}

The manual and automated LHDs were found to consume fuel at a rate of 0.27 and $0.19 \mathrm{~L} / \mathrm{t}$ of ore mined respectively (Moreau et al., 2019). By applying this $30 \%$ decrease to other pieces of equipment, such as haulage trucks and drill rigs, further emissions reductions can be expected. The complete list of LHDs, haulage trucks, drills and all other site equipment is provided in Table 6 below.

The $\mathrm{CO}_{2}$ emission factor used for diesel burned in heavy-duty equipment was $2681 \mathrm{~g} / \mathrm{L}$ of diesel fuel [16]. The reduction of underground diesel usage listed previously in Table $5(4.71 \mathrm{~L} / \mathrm{t}$ for scenario 1$)$ could have a large impact on the environmental footprint over the entire mine life, especially when projecting automation statistics to other machines and equipment $(3.53 \mathrm{~L} / \mathrm{t}$ for scenario 3$)$.

\subsection{Ventilation analysis}

Ventilation at the mine site contributes $32.3 \%$ of electric power consumption (the next highest consumption activities are grinding at $11 \%$, haulage and mucking at $9.9 \%$, flotation at $7.3 \%$, hoisting at $7 \%$

Table 7. GHG emission intensity factors of various electricity generation sources [17].

\begin{tabular}{llll}
\hline Source & \multicolumn{2}{l}{$\mathrm{g} \mathrm{CO}_{2}$ eq./kWh } & \\
\cline { 2 - 4 } & Mean & Low & High \\
\hline Lignite & 1054 & 790 & 1372 \\
Coal & 888 & 756 & 1310 \\
Oil & 733 & 547 & 935 \\
Natural gas & 499 & 362 & 891 \\
Solar PV & 85 & 13 & 731 \\
Biomass & 48 & 10 & 101 \\
Nuclear & 29 & 2 & 130 \\
Hydropower & 26 & 2 & 237 \\
Wind & 26 & 6 & 124 \\
\hline
\end{tabular}

and others, e.g. drilling, crushing, dewatering, etc., at $32.5 \%$ ). Depending on the electric power generation methods used in the area of the mine site, decreased ventilation demands could have a significant impact on $\mathrm{CO}_{2}$ emitted and the environmental footprint of mining operations. Table 7 lists the global average GHG intensity factors of various electricity generation methods for comparison [17].

Regulations stipulate that mines supply 100 cubic feet per minute $(\mathrm{cfm})$ of air per horsepower of diesel equipment in operation, which is consistent across various regions $[18,19]$. This is reflected in the reduced ventilation requirements in Table 5 for scenario 3 . The increased productivity projected for individual automated haulage trucks and drills reduces the number needed to maintain production rates, and the resulting environmental impacts were analyzed.

\subsection{Methodology and software}

Sphera's GaBi Solutions software [20] was used to compare the environmental impacts of extracting ore from an underground mine using both automated and manually operated equipment. The LCA software contains about 32,000 datasets developed from working globally with companies, associations and public bodies. It also offers a "Precious Metals" extension equipped with 28 processes, which was used in this study.

The required operating statistics were obtained from the mine's technical report forms, which provide material and technical information relating to activities occurring on the property. Resources containing statistical guides were also used when specific information was not provided within the technical report (e.g., power consumption for a mine hoist is $1 \mathrm{kWh} / \mathrm{t}$ for each $367 \mathrm{~m}$ of hoisting distance $[19,21])$. The data was inputted to the LCA software for specified operations on-site for a production period of one day. The results were extrapolated from mine life calculations of 18.3 and 13.5 years for manual and automated operations respectively, based on ore reserve estimates of 20 million tonnes.

Numerous methods are available for assessing the environmental impact of a project using the LCA output. Each method contains a variety of impact categories such as global warming potential, acidification, eutrophication and human toxicity. These four impact categories were selected to be studied based on their popularity within various LCA studies in the industry as well as the recommendations within the software itself. The method that was used for this study was TRACI version 2.1 (Tool for the Reduction and Assessment of Chemical and 
Table 8. GHGRP requirements for reporting selected GHGs by source [25].

\begin{tabular}{|c|c|c|c|c|c|c|c|c|c|}
\hline \multirow{3}{*}{ Greenhouse gas } & \multicolumn{9}{|c|}{ Emissions Source } \\
\hline & \multirow{2}{*}{$\begin{array}{l}\text { Stationary fuel } \\
\text { combustion }\end{array}$} & \multirow{2}{*}{$\begin{array}{l}\text { Industrial } \\
\text { process }\end{array}$} & \multirow{2}{*}{$\begin{array}{l}\text { Industrial } \\
\text { product use }\end{array}$} & \multicolumn{3}{|l|}{ Fugitive } & \multirow{2}{*}{$\begin{array}{l}\text { On-site } \\
\text { transport-ation }\end{array}$} & \multirow{2}{*}{\multicolumn{2}{|c|}{ Waste Wastewater }} \\
\hline & & & & Venting & Flaring & Leakage & & & \\
\hline Carbon dioxide & $\checkmark$ & $\checkmark$ & $x$ & $\checkmark$ & $\checkmark$ & $\checkmark$ & $\checkmark$ & $\checkmark$ & $\checkmark$ \\
\hline Methane & $\checkmark$ & $\checkmark$ & $x$ & $\checkmark$ & $\checkmark$ & $\checkmark$ & $\checkmark$ & $\checkmark$ & $\checkmark$ \\
\hline Nitrous oxide & $\checkmark$ & $\checkmark$ & $x$ & $\checkmark$ & $\checkmark$ & $\checkmark$ & $\checkmark$ & $\checkmark$ & $\checkmark$ \\
\hline Sulphur hexafluoride & $x$ & $\checkmark$ & $\checkmark$ & $x$ & $x$ & $x$ & $x$ & $x$ & $x$ \\
\hline Hydroflurocarbons & $x$ & by species & by species & $x$ & $x$ & $x$ & $x$ & $x$ & $x$ \\
\hline Perflurocarbons & $x$ & by species & by species & $x$ & $x$ & $x$ & $\mathrm{x}$ & $x$ & $x$ \\
\hline
\end{tabular}

Other Environmental Impacts), which was developed by the U.S. Environmental Protection Agency [22]. The TRACI method enables impact assessment for sustainability, life cycle assessment, industrial ecology, process design, and pollution prevention [23]. The methodology impact categories are said to be more suited to the USA, therefore it was chosen to assess the investigated mine site (Canada) rather than other methodologies that were European based [23].

\section{Results and discussion}

\subsection{Global warming potential}

Table 8 contains the reporting criteria required by the Canadian Greenhouse Gas Reporting Program (GHGRP) under which the studied mine falls. In 2017, the site reported $19,260 \mathrm{t}$ of $\mathrm{CO}_{2}$ eq. were emitted from their operations [24], whereas the LCA software calculated $22,437 \mathrm{t}$ of $\mathrm{CO}_{2}$ eq. production per year. The $15.2 \%$ increase was due to including mine camp related activities, employee travel to and from the workplace, and electrical energy consumption, within the LCA, none of which are included within the GHGRP. But for the purposes of a study which analyzes the mine's whole life span, these processes need to be included. The GHG emissions from the mine camp and electric energy consumption were calculated to be 1590 and $470 \mathrm{t}$ $\mathrm{CO}_{2}$ eq. respectively, which taken out would reduce the LCA calculated value to $20,377 \mathrm{t}$ of $\mathrm{CO}_{2}$ eq., which is only a $5.6 \%$ difference from the GHGRP reported emissions. The similarity of reported values and LCA results confirmed that reasonable operational data was gathered for this study and can be used for projecting long-term environmental

\begin{tabular}{lll} 
Table 9. Global warming potential results from investigated mine site. \\
\hline Scenario & $\mathrm{kg} \mathrm{CO} 2$ eq./t & $\begin{array}{l}\% \text { decrease } \\
\text { (from scenario 1) }\end{array}$ \\
\hline 1 & 20.5 & - \\
2 & 18.3 & $11.1 \%$ \\
3 & 16.8 & $18.3 \%$ \\
\hline
\end{tabular}

impacts by operations utilizing automated mining equipment.

Global warming potential was developed to compare the impacts of different GHGs emitted to air (e.g., $\mathrm{CO}_{2}, \mathrm{CH}_{4}, \mathrm{~N}_{2} \mathrm{O}, \mathrm{O}_{3}$ ) and is measured as equivalency to carbon dioxide $\left(\mathrm{kg} \mathrm{CO} \mathrm{CO}_{2}\right.$ eq.) [26]. The TRACI 2.1 assessment method uses Assessment Report 4 from the International Panel on Climate Change (IPCC) to measure global warming potential from GHG production. The IPPCs assessment report provides a current and comprehensive assessment of causes, impacts and response strategies to climate change and form a worldwide standard reference for academia, government and industry [27]. The results from the mining processes studied in the three investigated scenarios are presented in Table 9.

The transition to automated LHDs in scenario 2 resulted in an $11.1 \%$ decrease in global warming potential due to the mucking and backfill operations (Fig. 3). As LHD machines are primarily used within these operations they were expected to have the largest impact on $\mathrm{CO}_{2}$ emission reductions. The remaining contribution is primarily a result of the mine camp operations and decreased ventilation requirements.

The increase in productivity from using automated LHD equipment will lead to a shorter mine life when analyzing a project with a fixed amount of ore reserves. A shorter mine life reduces overall $\mathrm{CO}_{2}$ emissions and other impacts from the mine camp by eliminating years of on-site energy consumption, daily travel to and from the workplace, and also reduces landfill and wastewater. Automation is also expected to have an effect on the workforce required for operations. When the mine site becomes more experienced with the technology, a single operator can remotely control multiple machines at once from the surface.

For this study, it has been assumed that the mine site will utilize two machines per operator for LHDs, haulage trucks and drills, while also requiring additional specialized personnel for maintenance, 


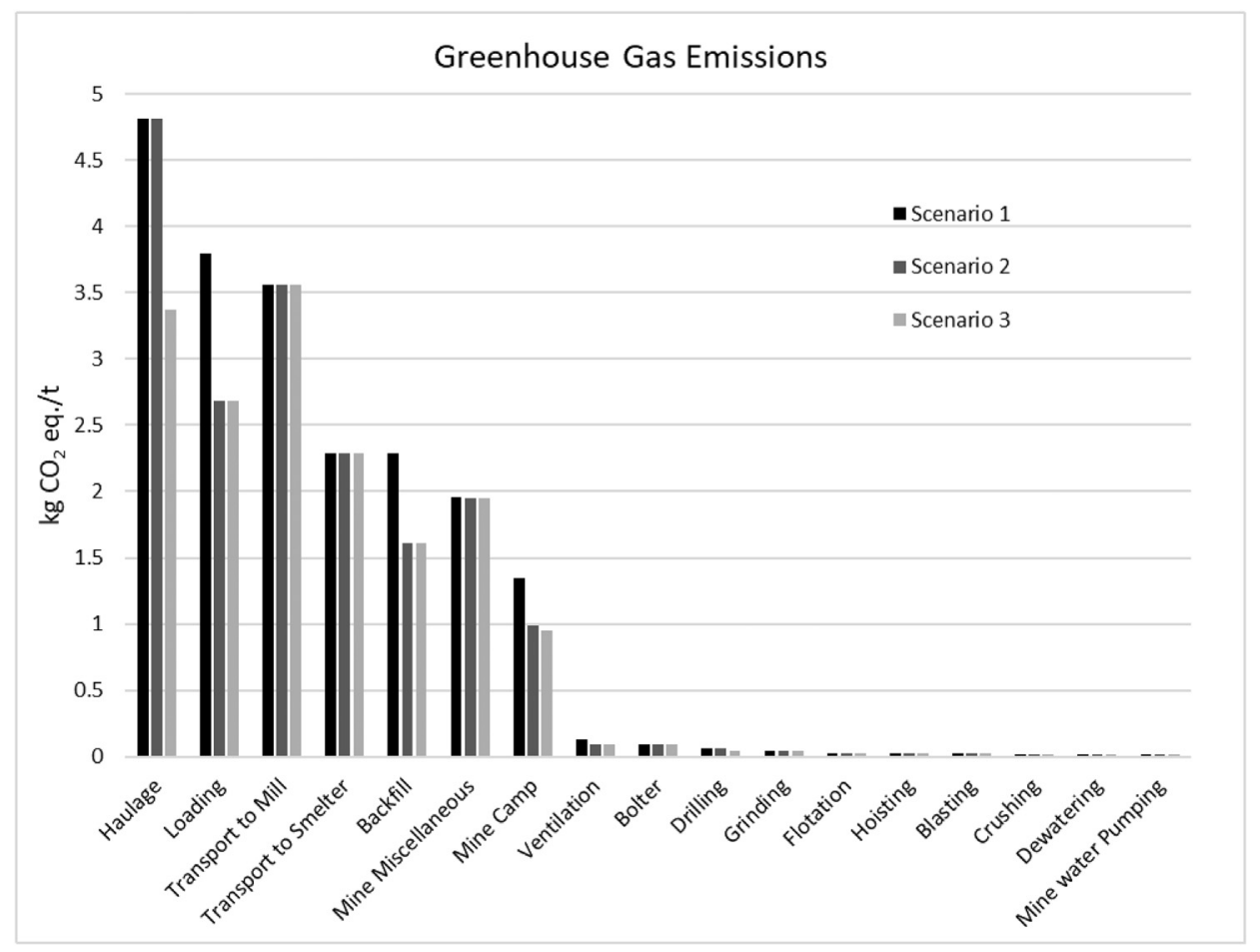

Fig. 3. Global warming potential breakdown of specified operations.

IT communication and project management relating to automated operations. This adjustment in workforce will further affect the travel to/from work as well as electricity consumption and waste disposal at the mine camp, all of which have been reflected within the mine camp process in Fig. 3.

When projecting the productivity gains and fuel efficiency from automated LHDs to haulage trucks and drills, a $18.3 \%$ reduction in $\mathrm{kg} \mathrm{CO}_{2}$ eq./t of ore was projected for the tested mine site operations. As seen in Fig. 3, a substantial portion of this reduction was contributed from the haulage and mucking operations. Drilling operations provided a reduction of $0.03 \mathrm{~kg}$ of $\mathrm{CO}_{2}$ eq./t of ore mined which represents less than $1 \%$ of the overall reduction in global warming potential from scenarios 1, 2 and 3. Drilling operations consist of minimal travel during shift time compared to haulage trucks and LHDs and are operated through the mine's electrical infrastructure when drilling. Therefore, as expected emissions from burning diesel fuel is significantly less for drilling operations compared to the continuous operation of haulage trucks and LHDs.

The results from the LCA confirmed the expectations of reducing the environmental impact from mine site operations that were heavily reliant on diesel fuel consumption. However, the impact was minimal when analyzing process operations that require electricity as their primary energy source, such as drilling and ventilation. Their impact is a factor of the electric energy generation methods used in the specific area where the mine is located. $98 \%$ of the electricity generated for the area is from renewable hydropower, which produces the lowest GHG emissions during operation as seen in Table 7 [17]. The remaining $2 \%$ is generated from natural gas resources and the average intensity factor was reported to be $3.4 \mathrm{~g} \mathrm{CO}_{2}$ eq. $/ \mathrm{kWh}$ in the

Table 10. Estimated GHG emission factor for electricity generation in Nevada, USA.

\begin{tabular}{llll}
\hline Source & $\begin{array}{l}\text { Monthly electricity } \\
\text { generation }(\mathrm{kWh})\end{array}$ & $\%$ Generation & $\mathrm{g} \mathrm{CO} 2$ eq./kWh \\
\hline Oil & $1.00 \times 10^{6}$ & $0.02 \%$ & 733 \\
Natural gas & $3.09 \times 10^{9}$ & $69.83 \%$ & 499 \\
Coal & $3.08 \times 10^{8}$ & $6.95 \%$ & 888 \\
Hydroelectric & $1.77 \times 10^{8}$ & $3.99 \%$ & 26 \\
Renewables (non- & $8.51 \times 10^{8}$ & $19.21 \%$ & 52 \\
$\quad$ hydroelectric) & & & \\
\hline
\end{tabular}




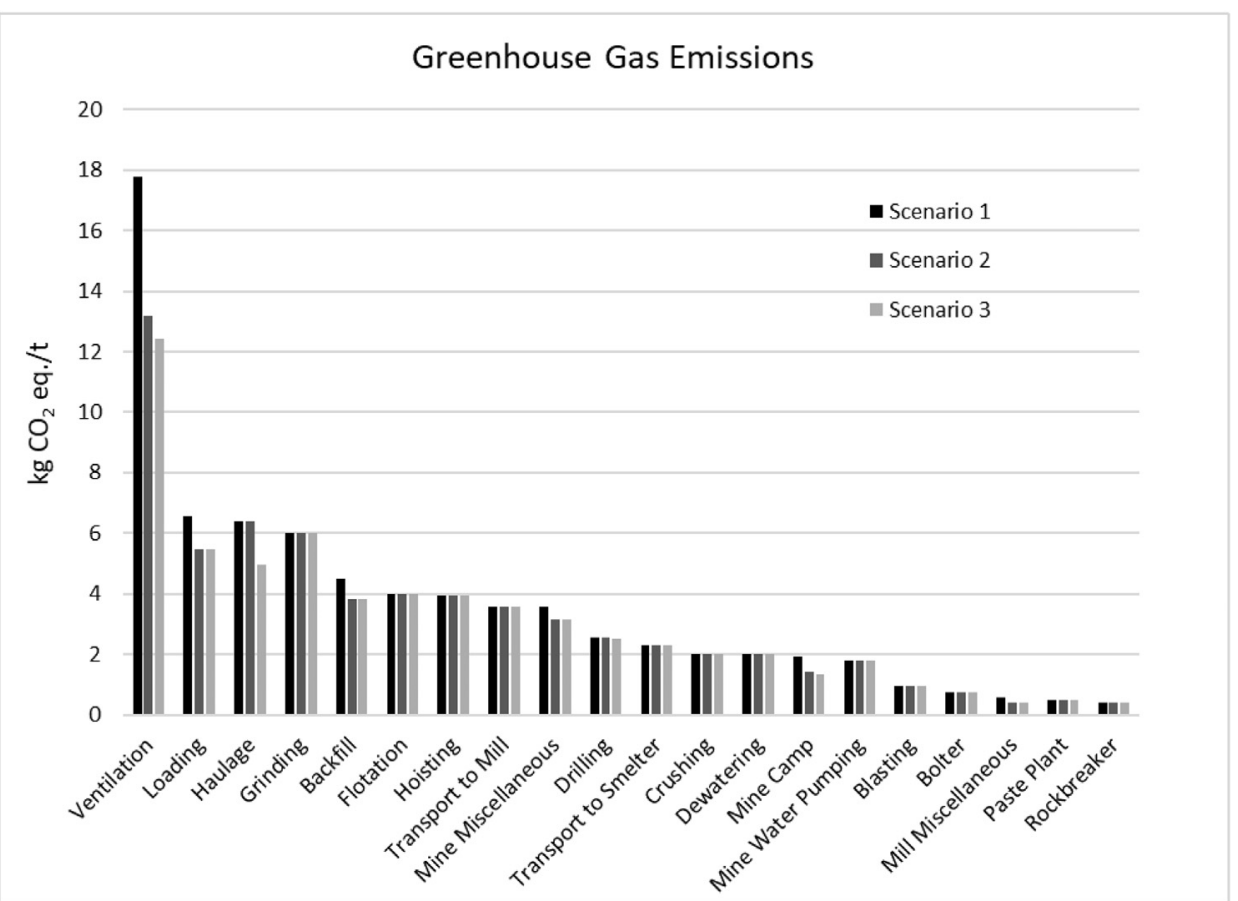

Fig. 4. Global warming potential breakdown of specified operations with an electric energy generation $\mathrm{GHG}$ intensity factor of $421.4 \mathrm{~g} \mathrm{CO}_{2}$ eq./ $\mathrm{kWh}$.

region of the mine's location [28]. The GHG intensity factor can vary depending on the method used for electricity generation in that area. For example, in Canada, areas that primarily utilize hydropower have lower GHG intensities (Quebec $1.2 \mathrm{~g} \mathrm{CO}_{2} / \mathrm{kWh}$ ), whereas areas using fossil fuels to generate electricity have GHG intensities as high as $790 \mathrm{~g} \mathrm{CO}_{2} / \mathrm{kWh}$ (Alberta) [28]. Future studies could involve a comparison of GHG intensity factors from different methods of electric energy generation and how this would affect ventilation, drilling and mine camp operations when using automated underground equipment.

The mine site operations were also examined as if it was located in a different area in the world, where it is assumed the main change is the type of electric energy generation. For example, based on the information provided in Table 10, the GHG emissions factor for electricity generation in Nevada, USA, was estimated to be $421.4 \mathrm{~g} \mathrm{CO}_{2}$ eq. per $\mathrm{kWh}$ compared to $3.4 \mathrm{~g} \mathrm{CO}_{2}$ eq. per $\mathrm{kWh}$ at the mine studied.

Operations relying on electricity as an energy source, such as ventilation and grinding, become some of the highest contributors to $\mathrm{CO}_{2}$ eq./t of ore in this situation. Ventilation is the highest contributor but also experiences the largest reduction when automation is introduced, as seen in Fig. 4. The total reduction from scenario 1 to 3 was calculated as $9.7 \mathrm{~kg} \mathrm{CO} 2$ eq. $/ \mathrm{t}$, whereas the reduction from ventilation was calculated to be $5.3 \mathrm{~kg} \mathrm{CO}$ eq./t, representing $55 \%$ of the total. This study shows that areas with high GHG intensity factors from electricity generation benefit more from limiting ventilation requirements compared to haulage or mucking. Further improvements can be made from other technologies such as battery-electric vehicles, which significantly reduce ventilation requirements, whereas areas with low GHG intensity factors from electricity generation should focus on automated technology and improving diesel fuel consumption.

\subsection{Acidification and eutrophication potential}

When analyzing environmental impacts of an operation or industry, the main focus is often on GHG emissions $\left(\mathrm{CO}_{2}\right.$ eq.), but the purpose of the

Table 11. Acidification and eutrophication potential results from investigated mine site.

\begin{tabular}{lllll}
\hline Scenario & $\mathrm{kg} \mathrm{SO}$ eq./t & $\begin{array}{l}\% \text { decrease } \\
\text { (from scenario 1) }\end{array}$ & kg N eq./t & $\begin{array}{l}\% \text { decrease } \\
\text { (from scenario 1) }\end{array}$ \\
\hline 1 & 0.307 & - & $3.74 \times 10^{-2}$ & - \\
2 & 0.277 & $9.8 \%$ & $3.56 \times 10^{-2}$ & $4.8 \%$ \\
3 & 0.254 & $17.3 \%$ & $3.42 \times 10^{-2}$ & $8.5 \%$ \\
\hline
\end{tabular}


Table 12. Process analysis for acidification potential.

\begin{tabular}{llll}
\hline Operation & \multicolumn{3}{c}{ Acidification Potential $(\mathrm{kg} \mathrm{SO}$ eq./t) } \\
\cline { 2 - 4 } & Scenario 1 & Scenario 2 & Scenario 3 \\
\hline Haulage & $7.5 \times 10^{-2}$ & $7.5 \times 10^{-2}$ & $5.3 \times 10^{-2}$ \\
Mucking & $5.9 \times 10^{-2}$ & $4.2 \times 10^{-2}$ & $4.2 \times 10^{-2}$ \\
Backfill & $3.6 \times 10^{-2}$ & $2.5 \times 10^{-2}$ & $2.5 \times 10^{-2}$ \\
Mine water pumping & $2.5 \times 10^{-2}$ & $2.5 \times 10^{-2}$ & $2.5 \times 10^{-2}$ \\
Mine camp & $8.1 \times 10^{-3}$ & $6.0 \times 10^{-3}$ & $6.0 \times 10^{-3}$ \\
Drilling & $1.6 \times 10^{-3}$ & $1.6 \times 10^{-3}$ & $1.1 \times 10^{-3}$ \\
\hline
\end{tabular}

LCA we have developed is to provide the analysis for several environmental impacts (i.e., acidification, eutrophication and human health). Acidification potential is a measurement of air pollutants, sulfur dioxide and nitrogen oxide, transmitted to the atmosphere and deposited as acids $\left(\mathrm{H}_{2} \mathrm{SO}_{4}\right.$ and $\mathrm{HNO}_{3}$ ) in surface soils and waters [29]. Acidification impacts the environment through rainwater, soil, groundwater, surface water, and biological organisms leading to fish mortality, forest dieback, and the deterioration of building materials [30].

Eutrophication potential is an increase in nutrient concentration, primarily phosphorus and nitrogen, deposited to aquatic or terrestrial areas from human activities, such as chemical fertilizer application or wastewater discharges [31]. Nutrient richness may result in a shift in species composition and increased biomass production in both aquatic and terrestrial ecosystems, leading to depressed oxygen levels and unsatisfactory sources of drinking water [30]. Typically, phosphorus is used to measure eutrophication, but for the purposes of this study nitrogen equivalents will be used due to the higher concentration of nitrogen, compared to phosphorus, in discharge water from explosives used in the underground mining process.

The acidification potential for each scenario was measured based on mass of $\mathrm{SO}_{2}$ eq. and presented in Table 11. The data obtained from the automation trial period resulted in $9.8 \%$ decrease in calculated $\mathrm{SO}_{2}$ equivalent, while projecting the automation statistics for haulage trucks and drills, a decrease of $17.3 \%$ was estimated.

The use of automated equipment resulted in a decrease of $4.8 \%$ and $8.5 \%$ for scenarios 2 and 3 respectively. Tables 12 and 13 list some of the key operations at the mine site and it can be seen that the main contribution towards eutrophication potential is mine water pumping, and more specifically the disposal of wastewater containing ammonia, nitrate, and nitrites. This is unchanged throughout scenarios 1-3 and, therefore, the implementation of automated equipment did not have as significant of an impact compared to acidification potential,
Table 13. Process analysis for Eutrophication potential.

\begin{tabular}{llll}
\hline Operation & \multicolumn{3}{l}{ Eutrophication Potential $(\mathrm{kg} \mathrm{N}$ eq./t) } \\
\cline { 2 - 4 } & Scenario 1 & Scenario 2 & Scenario 3 \\
\hline Mine water pumping & $2.5 \times 10^{-2}$ & $2.5 \times 10^{-2}$ & $2.5 \times 10^{-2}$ \\
Haulage & $4.5 \times 10^{-3}$ & $4.5 \times 10^{-3}$ & $3.1 \times 10^{-3}$ \\
Mucking & $3.5 \times 10^{-3}$ & $2.5 \times 10^{-3}$ & $2.5 \times 10^{-3}$ \\
Backfill & $2.1 \times 10^{-3}$ & $1.5 \times 10^{-3}$ & $1.5 \times 10^{-3}$ \\
Mine camp & $4.9 \times 10^{-4}$ & $3.6 \times 10^{-4}$ & $3.6 \times 10^{-4}$ \\
Drilling & $9.6 \times 10^{-5}$ & $9.6 \times 10^{-5}$ & $6.8 \times 10^{-5}$ \\
\hline
\end{tabular}

where haulage and mucking processes are large contributors and are affected by automation technology.

\subsection{Human toxicity}

An additional aspect of an LCA is to relate environmental impacts to human health. For this, human toxicity potential is used as a measure of impacts from chemical emissions released into the environment [32]. The LCA software calculates human toxicity using the USEtox ${ }^{\circledR}$ scientific consensus model which calculates characterization factors for human toxicity by assessing the toxicological effects of a chemical emitted into the environment through environmental fate, exposure and effects [33]. Human toxicity is measured in Comparative Toxic Units (CTUh), which is an estimation of increased morbidity per unit mass of chemical emissions [33]. The results for scenarios 1-3 are listed in Table 14.

The CTUh decreased $19.2 \%$ when implementing automated LHDs and projecting the productivity and fuel consumption statistics to haulage trucks and drills. This means over the entire mine life it is expected to experience approximately 11 fewer disease cases amongst humans from chemicals emitted from the mining processes used in scenarios 1 and 3. The calculation is based on both cancerous and non-cancerous effects derived from laboratory studies [33].

\subsection{Discussion}

The implementation of automation was found to have a significant impact on all the investigated

Table 14. Human toxicity potential comparison using USEtox ${ }^{\circledR}$ scientific consensus model.

\begin{tabular}{|c|c|c|c|}
\hline Scenario & CTUh/t & $\begin{array}{l}\text { Mine life disease cases } \\
(20 \text { million tonnes of ore) }\end{array}$ & $\begin{array}{l}\% \text { decrease } \\
\text { (from scenario 1) }\end{array}$ \\
\hline 1 & $2.96 \times 10^{-6}$ & 59.2 & - \\
\hline 2 & $2.63 \times 10^{-6}$ & 52.6 & $11.2 \%$ \\
\hline 3 & $2.39 \times 10^{-6}$ & 47.8 & $19.2 \%$ \\
\hline
\end{tabular}


impact categories. Previously reported GHG emissions from underground copper operations had a range of $1-9 \mathrm{t} \mathrm{CO} / \mathrm{t} \mathrm{Cu}$. metal [11]. The results from the current study for the global warming potential of the mines site under current manual operations (scenario 1: $20.5 \mathrm{~kg} \mathrm{CO}_{2} / \mathrm{t}$ ore) is, based on actual copper metal production $(6400 \mathrm{t} / \mathrm{a}), 3.51 \mathrm{t}$ $\mathrm{CO}_{2} / \mathrm{t} \mathrm{Cu}$., which falls within the range suggest by Northey et al., (2013). Whereas, with the use of automated LHDs, haulage trucks and drills (scenario $3 ; 16.8 \mathrm{~kg} \mathrm{CO}_{2} / \mathrm{t}$ ore) it is equivalent to $2.88 \mathrm{t}$ $\mathrm{CO}_{2} / \mathrm{t} \mathrm{Cu}$. This $18 \%$ reduction in GHG emissions was primarily from operations that use diesel fuel as an energy source (Fig. 3). Mucking, haulage, and backfill were responsible for $87.6 \%$ of total emission reductions due to an increase in fuel efficiency and the ability to operate with fewer machines while maintaining desired productivity levels. The remaining reductions were from the mine camp facilities $(10.9 \%)$, ventilation $(1.1 \%)$, and drilling $(0.4 \%)$, which are a result of lower energy consumption and less employee travel due to the $27 \%$ decrease in operational mine life.

The current study was extended to analyze how the GHG intensity factor for electricity generation would affect the results. The mine site examined is located in a region that generates electricity with a low level of GHG emissions ( $3.4 \mathrm{~g} \mathrm{CO}_{2} / \mathrm{kWh}$ ), and the developed LCA model was modified to include a GHG intensity factor of $421.4 \mathrm{~g} \mathrm{CO}_{2} / \mathrm{kWh}$. This was estimated based on the electricity generation methods used in a different region (Nevada) and was studied because of the diversity of methods (oil, natural gas, coal, hydropower and other renewables) compared to the actual region of the mine which was heavily dominated by hydropower electricity generation (98\%). The results shown in Fig. 4 indicate that operations that use electricity as a fuel source, such as ventilation, grinding, floatation and hoisting, surpass some of the diesel operations (haulage, loading, and backfill) with regards to $\mathrm{CO}_{2}$ emissions. Therefore, operations that contribute the most to GHG emissions will depend on the GHG intensity factor for electricity generation.

The intensity factor for electricity generation is one parameter that could influence the total GHG emissions produced from an underground metal mine, as well as influence which operations should be targeted for potential reductions through the use of technologies such as automated vehicles. But the results of all LCA impact categories (Fig. 5), provide a more comprehensive site-specific analysis of environmental benefits, or otherwise, from introducing automation.

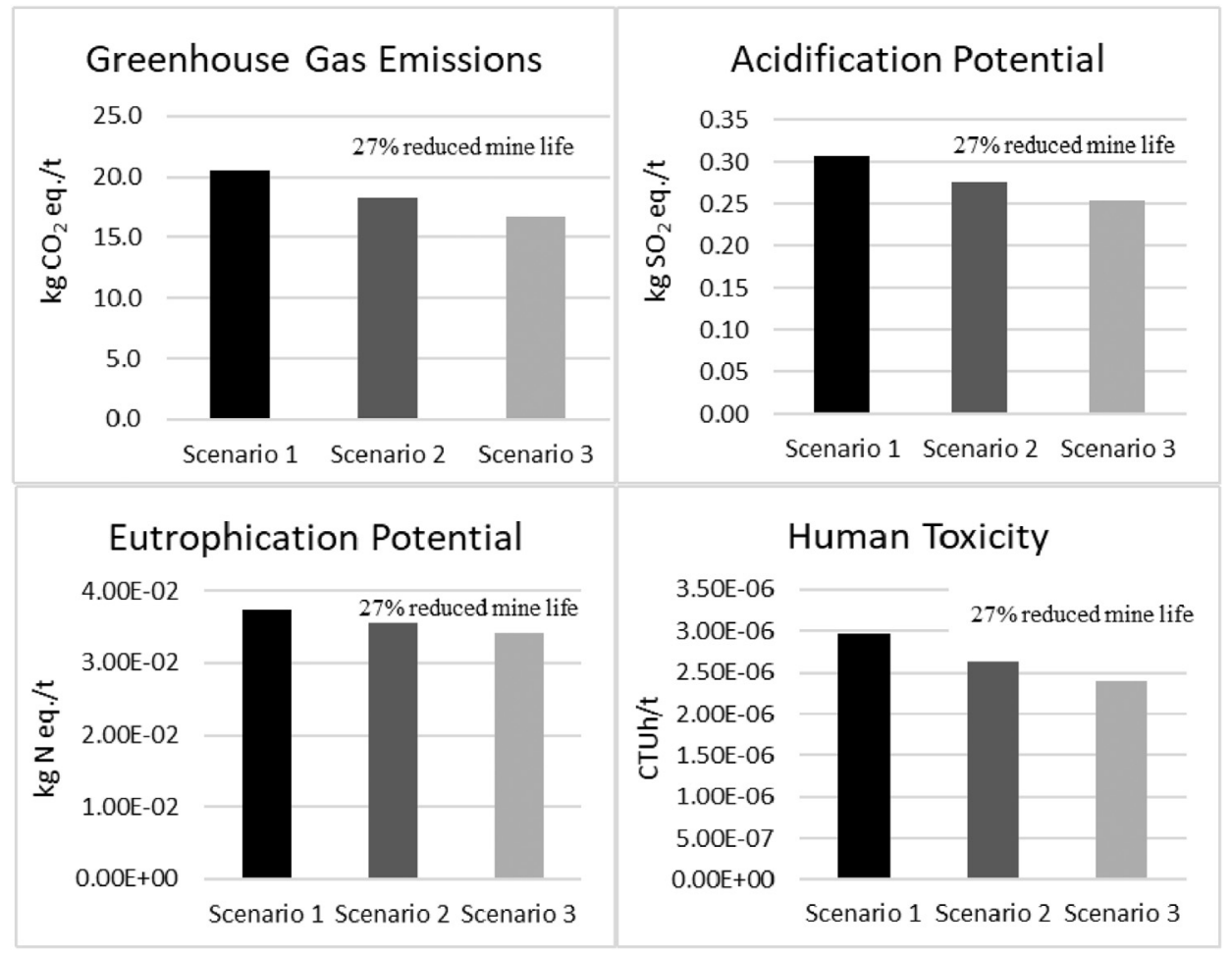

Fig. 5. Impact category results for investigated scenarios calculated using the LCA software (scenarios 2 and 3 reflect the impact of a reduction in the required operational life of the mine due to automation). 


\section{Conclusions}

Mining companies worldwide are carrying out economic evaluations of introducing automation, not least as they continue to search for more profitable methods of extracting ore at great depths. What is less considered are any impacts on the environment from increasing the level of automation. This can be addressed by using a life cycle assessment (LCA) approach, which shows that implementation of automated equipment reduces a range of environmental benefits. For the mine studied, overall global warming potential was decreased by $11.1 \%$ with automated LHD machines and by $18.3 \%$ when projecting LHD productivity and fuel efficiency data to other machines, such as haul trucks and drills. Utilizing automated equipment, the ore body can be extracted at a higher daily rate, which decreased mine life by $27 \%$ or 5 years. This is very significant not just in improved environmental impacts, but also for the economics of mine investment and payback.

For the site investigated, the results displayed significant environmental impact reductions with processes relying on diesel fuel for operations. Whereas, processes that primarily used electrical energy did not contribute a significant reduction in $\mathrm{CO}_{2}$ emissions due to the low GHG intensity of the main electricity generation method (hydropower) used by power plants that suppled the mine. However, by applying the developed LCA approach to worldwide locations that use other types of electricity generation (e.g., coal or natural gas) the introduction of automation will have an even greater impact on GHG emissions due to ventilation, grinding, drilling and mine camp operations. The results from this paper along with the analysis of these parameters can be used, therefore, to model the impacts from mine sites in general looking to implement automated technology to improve safety, productivity and environmental performance.

\section{Ethical statement}

The authors state that the research was conducted according to ethical standards.

\section{Funding body}

This work was supported by the Mitacs Accelerate Program partnered with Sudbury Integrated Nickel Operations [IT11703].

\section{Conflict of interest}

None declared.

\section{References}

[1] Ferreira H, Leite MGP. A Life Cycle Assessment study of iron ore mining. J Clean Prod 2015;108:1081-91. https:// doi.org/10.1016/j.jclepro.2015.05.140.

[2] Chadwick J. The autonomous mine. Int Min 2010;6:46-57.

[3] Gustafson A. Automation of load haul dump machines [Research report]. Luleå, Sweden: Luleå University of Technology; 2011.

[4] Chadwick J. Rise of the machines 2005;192:15-7.

[5] McNab K, Garcia-Vasquez M. Autonomous and remote operation technologies in Australian mining. Brisbane City, Australia: Centre for Social Responsibility in Mining (CSRM) - Sustainable Minerals Institute, University of Queensland; 2011.

[6] Dragt BJ, Camisani-Calzolari FR, Craig IK. An overview of the automation of load-haul-dump vehicles in an underground mining environment. IFAC Proc 2005;38:37-48. https://doi.org/10.3182/20050703-6-CZ-1902.01389.

[7] Gustafson A, Schunnesson H, Kumar U. Reliability analysis and comparison between automatic and manual load haul dump machines. Qual Reliab Eng Int 2015;31:523-31. https:// doi.org/10.1002/qre.1610.

[8] Bellamy D, Pravica L. Assessing the impact of driverless haul trucks in Australian surface mining. Res Pol 2011;36:149-58. https://doi.org/10.1016/j.resourpol.2010.09.002.

[9] Reid C, Bécaert V, Aubertin M, Rosenbaum RK, Deschênes L. Life cycle assessment of mine tailings management in Canada. J Clean Prod 2009;17:471-9. https:// doi.org/10.1016/j.jclepro.2008.08.014.

[10] Haque N, Norgate T. Life cycle assessment of iron ore mining and processing. 2015. p. 615-30. https://doi.org/ 10.1016/B978-1-78242-156-6.00020-4.

[11] Northey S, Haque N, Mudd G. Using sustainability reporting to assess the environmental footprint of copper mining. J Clean Prod 2013;40:118-28. https://doi.org/10.1016/ j.jclepro.2012.09.027.

[12] Moreau K, Bose R, Shang H, Scott JA. Automation to increase productivity and reduce energy consumption in deep underground mining operations. Comer Ind Madera (CIM) J 2019;10:115-24. https://doi.org/10.15834/cimj.2019.11.

[13] ISO 14040. Environmental management - life cycle assessment - principles and framework. International Organization for Standardization; 2006.

[14] Darling P. Automation and robotics. In: Darling P, editor. SME mining engineering handbook. $3^{\text {rd }}$ ed. Englewood, Colo: Society for Mining, Metallurgy, and Exploration; 2011.

[15] Paraszczak J, Gustafson A, Schunnesson H. Technical and operational aspects of autonomous LHD application in metal mines. Int J Min Reclamat Environ 2015;29:391-403. https:// doi.org/10.1080/17480930.2015.1086553.

[16] Government of Canada. Emission factors - national inventory report 1990-2017: greenhouse gas sources and sinks in Canada [internet]. 2019. Retrieved from: https://open. canada.ca/data/en/dataset/779c7bcf-4982-47eb-af1ba33618a05e5b.

[17] World Nuclear Association. Comparison of lifecycle greenhouse gas emissions of various electricity generation sources [internet]. UK: WNA; 2011. Retrieved from: http://www. worldnuclear.org/uploadedFiles/org/WNA/Publications/ Working_Group_Reports/comparison_of_lifecycle.pdf.

[18] Campbell H, Seeber C, Wywrot J. Ventilation Part 1 [internet]. Canada: Canadian Mining Journal; 2003. Retrieved from: https://www.canadianminingjournal.com/ features/ventilation-part-1.

[19] De la Vergne J. Engineering. M. Hard rock miners handbook: rules of thumb. North Bay, Ont.: McIntosh Engineering; 2003.

[20] Sphera. GaBi Solutions [software]. USA: Sphera; 2020. Retrieved from, http://www.gabi-software.com/canada/ index/. 
[21] Canadian Industry Program for Energy Conservation (CIPEC). Benchmarking the energy consumption of Canadian underground bulk mines. Natural Resources Canada; 2005.

[22] Bare J. TRACI 2.0: the tool for the reduction and assessment of chemical and other environmental impacts 2.0. Clean Technol Environ Policy 2011;13:687-96. https://doi.org/ 10.1007/s10098-010-0338-9.

[23] Menoufi K, Casol A, Cabeza L. Life cycle analysis and life cycle impact assessment methodologies [Master's Thesis]. Lleida, Spain: University of Lleida; 2011.

[24] Government of Canada. Greenhouse Gas Report 2004 - 2017 [internet]. 2019. Retrieved from: https://open.canada.ca/data/ en/dataset/a8ba14b7-7f23-462a-bdbb-83b0ef629823.

[25] Canada Gazette. Government Notices, Part I [internet]. 2019. Retrieved from, http://gazette.gc.ca/rp-pr/p1/2019/2019-0119/html/notice-avis-eng.html.

[26] United States Environmental Protection Agency. Greenhouse Gas Emissions, Understanding Global Warming Potentials [internet]. USA: EPA; 2017. Retrieved from, https:// www.epa.gov/ghgemissions/understanding-globalwarming-potentials.

[27] Parry ML, Canziani O, Palutikof JP, van der Linden P, Hanson CE. Climate Change 2007: Impacts, Adaptation and Vulnerability. Contrib. Work. Gr. II to Fourth Assess. Rep. Intergov. Panel Clim. Chang.. 2007.

[28] Government of Canada. Canada's Renewable Power Landscape 2017 - Energy Market Analysis [internet]. 2017.
Retrieved from, https://www.cerrec.gc.ca/nrg/sttstc/lctrct/ rprt/2017cndrnwblpwr/ghgmssn-eng.html.

[29] Pacheco-Torgal F. 1 - introduction to biopolymers and biotech admixtures for eco-efficient construction materials. In: Pacheco-Torgal F, Ivanov V, Karak N, Jonkers H, editors. Biopolym. Biotech admixtures eco-efficient constr. Mater Woodhead Publishing; 2016. p. 1-10. https://doi.org/10.1016/ B978-0-08-100214-8.00001-4.

[30] Guinée JB, Lindeijer E. Handbook on Life Cycle Assessment: Operational Guide to the ISO Standards. Springer Netherlands; 2002.

[31] Kim T, Chae C. Environmental impact analysis of acidification and eutrophication due to emissions from the production of concrete. Sustainability 2016;8:578. https://doi.org/ $10.3390 /$ su8060578.

[32] Hertwich E, Mateles S, Pease W, McKone T. Human toxicity potentials for life-cycle assessment and toxics release inventory risk screening. Environ Toxicol Chem 2001;20: 928-39. https://doi.org/10.1897/1551-5028(2001)020<0928: HTPFLC $>2.0$. CO. 2.

[33] Rosenbaum RK, Bachmann TM, Gold LS, Huijbregts MAJ, Jolliet O, Juraske R, et al. USEtox - the UNEP-SETAC toxicity model: recommended characterisation factors for human toxicity and freshwater ecotoxicity in life cycle impact assessment. Int J Life Cycle Assess 2008;13:532. https:// doi.org/10.1007/s11367-008-0038-4. 